\title{
A Diverse and Inclusive Psychological Work Climate: Some Antecedents and Consequences
}

\author{
Marie-Élène Roberge \\ Roosevelt University
}

\author{
Wen-Rou Huang \\ National Chung Cheng University \\ Qiumei Jane Xu \\ Northeastern Illinois University
}

\begin{abstract}
This paper presents an organizational field study that examines some antecedents and consequences of a diverse and inclusive psychological work climate. 23 managers participated in a survey after completing a diversity training. The results found support for a tri-dimensional conceptualization of a psychological inclusive climate. ANOVAs analyses were conducted to determine whether the results support the hypotheses. The findings show significance for some antecedents on both psychological climates, such as time worked for the organization, perception of an inclusive leadership, and personal comfort with diversity. As for the consequences, significant relationships were found between a psychological diversity climate and three attitudinal variables: job satisfaction, job training satisfaction, and organizational commitment. As for the psychological inclusive climate, the results showed significance only with job satisfaction and job training satisfaction. The theoretical implications of this study are discussed, and the practical applications of the findings are explained in hope to guide the creation of diverse and inclusive work climates that relist the positive outcomes that can be reached by a diverse workforce.
\end{abstract}

Keywords: psychological diversity climate, psychological inclusive climate, antecedents, consequences, organizational field study

\section{INTRODUCTION}

In today's workplace, managing diversity successfully requires fostering a work climate that provides the proper environment for diversity to thrive and to be successful at resolving conflicts and integrating information about differences which, in turn, lead to increase creativity and innovation, improve the quality of decision-making process, and therefore enhance performance. Such environment has been described as diverse and inclusive. In this study, we focus our attention on the managers' individual perception of a diverse and inclusive psychological work climate (Doghan, Bhatti \& Juhari, 2019). A psychological work climate was defined as employee cognitive judgment of his/her work environment that leads to a perception about his or her organization that is significant to the individual (James, Choi, 
Ko, McNeil, Minton, Wright \& Kim, 2008). Since the literature considers a diversity climate and inclusive climate as being factors of an appropriate environment in which diversity can relish its full potential (Roberson, 2019; Van Knippenberg, Nishii, \& Dwertmann, 2020), our study focuses on both psychological work climates. First, the study explores the underlying psychological dimensions that conceptualize the concept of a psychological inclusive climate. Then, it examines some antecedent variables and individual consequences of both psychological work climates.

Few empirical studies (Mor Barak \& Cherin 1998; Mor Barak, Cherin, \& Berkman, 1998; Nishii, 2003) has examined the conceptualization of a psychological diversity climate and a psychological inclusive climate. Only some studies have investigated the antecedents that may predict the emergence of such climates (Li, Perera, Kulik \& Metz, 2019). There is also only a small body of research (Mor Barak, Lizano, Kim, Duan, Rhee, Hsiao, \& Brimhall, 2016) that examines the consequences of such psychological work climates. Therefore, our study contributes to the literature by addressing three research questions. First, we explore what are the underlying dimensions that describe being working under a psychological inclusive climate? Second, we ask what are the antecedents that contribute to create both psychological work climates? Third, we investigate what are the attitudinal and behavioral consequences, that are predicted by both psychological work climates? Our proposed theoretical model provides some answers to these research questions.

\section{THE PROPOSED THEORETICAL MODEL}

We present a conceptual model that considers both a psychological diversity climate and a psychological inclusive climate as being mediators of the relationship between some antecedents, and individual consequences. Our measurement of an inclusive climate is multidimensional. We measure it by referring to three established and related concepts which are: justice, support, and psychological safety. In our model, both psychological climates mediate the relationship between four antecedent variables (i.e., diversity attributes, perception of inclusive leadership, perceptions of openness to diversity, and comfort with diversity), and five individual outcomes (i.e., job satisfaction, job training satisfaction, organizational commitment, voice behavior, and prohibitive behavior).

FIGURE 1

\section{THE THEORETICAL MODEL OF THE MEDIATING EFFECTS OF A DIVERSE AND INCLUSIVE PSYCHOLOGICAL WORK CLIMATE}

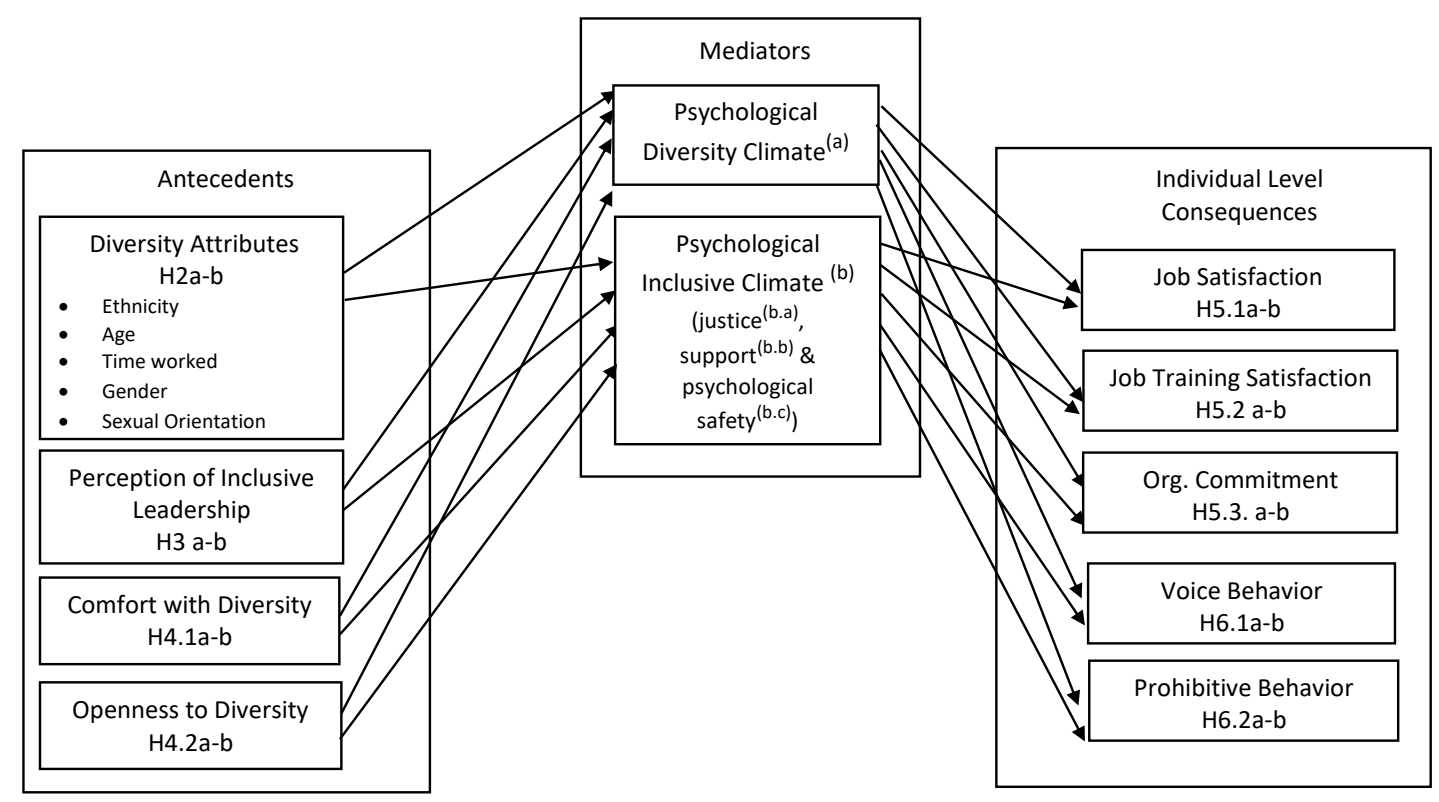




\section{LITERATURE REVIEW AND HYPOTHESES DEVELOPMENT}

\section{Psychological Diversity Climate}

Diversity climate has been defined as "the extent that employees view an organization as utilizing fair personnel practices and socially integrating all personnel into the work environment (McKay, \& Avery, 2015, p. 191)". The literature suggests that diversity climate is complex and multifaceted (Dwertmann, Nishii, \& van Knippenberg, 2016; Herdman \& McMillan-Capehart, 2010; Holmes IV, Jiang, Avery, McKay, Oh, \& Tillman, 2020). According to Chrobot-Mason and Aramovich (2013, p. 663), an "affirming climate" for diversity consists of a multitude of management practices that create a work environment defined as providing equal access and fair treatment to all. The creation of a pro-diversity climate depends on employee perceptions that diversity is valued and the extent to which diverse employees are encouraged to contribute fully to the organization (Joshi \& Roh, 2013). The employees' perception of working in a pro-diversity climate gives an important message that their organization is perceived to be free from biases and that it cares for the well-being of all their employees. In return, in a reciprocal perspective, employees will show positive attitudes such as a high level of job satisfaction and commitment, leading to increase performance (McKay, Avery, Liao, \& Morries, 2011).

\section{Psychological Inclusive Climate}

Research suggests that an inclusive climate emerges when people are working in a diverse organization in which they feel fairly treated (MorBarak et al., 1998), supported in their identities, and welcome to safely express their voice during the decision-making process (Nishii, 2013). Based on the literature, we propose that these three underlying psychological dimensions (i.e., justice, support, and psychological safety) are at the core of conceptualizing a psychological inclusive climate. Under such working conditions, research suggests that workers' response to such a positive work climate by displaying positive performance outcomes such a high level of job satisfaction and job training satisfaction, organizational commitment, and a high level of voice behaviors and prohibitive behaviors. Thus, we propose that a psychological inclusive climate is a multi-dimensional mediator that explains the relationship between some antecedent variables and individual consequence variables.

Justice

Justice is defined as individual's perception of whether the organization treats them fairly. Justice is reflected by employees' perception of being fairly treated throughout the distribution and allocation of the resources (i.e. distributive justice), the decision making processes implemented in the organization (i.e., procedural justice), the information provided to explain the decisions making processes and its related outcomes (i.e., informational justice), and the interpersonal treatment experienced by group members during social interactions (i.e., interpersonal justice) (Colquitt, Conlon, Wesson, Porter, \& Ng, 2001). For example, fairness is reflected by achieving a diverse workforce whose members are treated with dignity and provided with equal opportunities. Fair practices in organizations build up a foundation to eliminate biases and discrimination.

Researchers suggest that justice perception plays an important role in understanding an inclusive climate (Buttner, Lowe, \& Billings-Haris, 2010; Shore, Cleveland, \& Sanchez, 2018). For example, Hicks-Clarke and Iles (2000) emphasized the importance of justice as one major dimension of an inclusive climate by stating that it refers to employees' fairness perceptions of the organization in terms of its management processes used to allocate opportunities. Fairness perceptions relate to whether the organization puts efforts into the prevention and resolution of discriminatory treatments.

Researchers most often include fairness in their operationalization of an inclusive climate. For example, in a study conducted by Mor Barak and colleagues (1998), inclusive climate was measured by including an organizational fairness factor. Therefore, we believe that justice is a latent construct of a psychological inclusive climate. 


\section{Support}

According to organizational support theory (Eisenberger, Armeli, Rexwinkel, Lunch \& Rhoades, 2001; Gower, Forster, Gloppen, Johnson, Eisenberg, Connett, \& Borowsky, 2018; Luthans, Norman, Avolio, \& Avey, 2008; Shore \& Shore, 1995), a supportive work climate is defined as employees' shared perceptions of the extent to which the organization and its members value their contributions and care about their well-being. As pointed out by Rhoades and Eisenberger (2002), perceived organizational support helps the organizational members to deal with stressful situations such as in times of conflicts or interpersonal challenges, which are likely to occur in diverse group settings. Stamper and Masterson (2002) found that perceived organizational support leads to the feeling of being an insider at work, which positively influences work behavior.

Research suggests that diverse organizations are more likely to create an inclusive climate when the organizational strategy is committed to support diversity initiatives by implementing human resource practices that are diversity related such as providing training programs about diversity and inclusion, celebrating diversity and its related holidays, conducting team building activities, providing mentoring programs, involving newly hired employees into a socialization process, and organizing networking events (Roberge, Lewicki, Hietapelto \& Abdyldaeva, 2011). Such supportive managerial practices influence the emergence of a diverse and inclusive psychological climate and therefore increases organizational attachment, reduce employees' absenteeism and turnover, and enhance job satisfaction, job training satisfaction, organizational commitment and ultimately organizational performance (Eisenberger, et al., 1997; Gonzalez \& Denisi, 2009; Kochan, Bezrukova, Ely, Jackson, Joshi, Jehn, Leonard, Levine \& Thomas, 2003; Luthans et al. 2008; McKay, et al., 2008).

Employees are more likely to be validated in their identities when they feel supported by their peers and the organization. We believe that the emergence of a diverse and inclusive psychological climate encourages individuals to bring forward and share with other group members their "unique identity". This self-disclosure facilitates the social learning process and the integration of knowledge, skills, experiences, insights, and identities from diverse employees. By welcoming and supporting self-disclosures, the climates contribute to activate identity confirmation among group members (Milton \& Westphal, 2005). Such a social context makes employees feel valued and accepted for being members of the group as well as for their unique contribution, leading them to be able to freely express who they are. Thus, feeling supported captures the positive responses employees receive from their organization and its group members when differences are expressed. We propose that a psychological inclusive climate should include the dimension of support.

\section{Psychological Safety}

We propose that the third dimension of a psychological inclusive climate is psychological safety defined as "feeling able to show and employ oneself without fear of negative consequences to self-image, status, or career" (Kahn, 1990, p. 708). It is reflected in the possibility of choosing one's own work style and maintain important cultural habits, even when these habits may differ from what it is perceived as being the norm (Luijters, Van der Zee, \& Otten, 2008). For example, people with certain religious beliefs may pray in the workplace, even if most employees do not participate in such religious practice at work. Being able to freely express the self within the work environment is a value at the core of feeling psychologically safe. Thus, an important aspect of psychological safety is employees' feelings of being able to communicate openly about their respective differences and potential problems that may arise among themselves without fearing rejection ((Edmondson, 1999; Luijters et al. 2008). For example, Baer and Frese (2003) measured psychological safety by using items such as: "As an employee in our company one is able to bring up problems and tough issues".

Psychological safety indeed fulfills the need of inclusiveness (Shore, et al. 2011). By nature, it is an emotional construct referring to the absence of discrimination and fear of being rejected, while it also refers to the perception of being accepted and considered by other members and the group at large (Frazier, Fainshmidt, Kling, Pezeshkan, \& Vracheva, 2017). In a highly psychologically safe work environment, employees are likely to self-disclose their identity with others, leading them to identify with 
one another more easily and to engage in validating each other's identity in relationship with their group membership and their uniqueness (Leonardelli, Pickett, \& Brewer, 2010; Roberge \& van Dick, 2010). In other words, the processes of social identification and identity confirmation among group members are activated while the environment is perceived as being psychologically safe, which then contributes to the feeling of inclusiveness. Therefore, our first hypothesis is as followed:

Hypothesis 1: A psychological inclusive climate is composed of three underlying psychological dimensions: justice, support, and psychological safety.

\section{Antecedent Variables}

The emergence of a diverse and inclusive psychological climate may reside into the effect of variables such as the diversity of the group, the perception of an inclusive leadership, comfort with diversity, and openness to diversity.

\section{Diversity and Its Attributes}

Diversity has been defined as differences between individuals on any attribute that may lead to the perception that another person is different from the self (van Knippenberg, De Dreu, \& Homan, 2004). These attributes may be visible or invisible. Visible diversity refers to observable demographic characteristics such as gender, race, ethnicity, or age, whereas invisible diversity are non-observable characteristics such as education, socio-economic status, sexual orientation, religious beliefs, personality traits, abilities/disabilities. Visible attributes are mostly perceived first, at the beginning of interpersonal relationships, and may lead to stereotyping others who are perceived as being different. Invisible attributes are usually perceived once the group members have been interacting and getting to know each other on a deeper level. Theories, such as social identity (Tajfel, 1978) and self-categorization (Reimer, Schmid, Hewstone, \& Ramiah, 2020; Turner, Hogg, Oakes, Reicher, \& Wetherell, 1987), suggest that if these attributes are perceived as differences among group members, they create disparities, stereotyping and conflicts in between group members and therefore lower performance.

Because of such possibility in today's organizations, managing diversity effectively has become common concerns (Roberge, Lewicki, Hietapelto, \& Abdyldaeva, 2011). In the scientific literature, diversity management has been explosive. There have been tremendous efforts in proposing new research ideas that may help diversity to lead to positive performance outcomes. For example, Chatman, Polzer, Barsade and Neal (1998) found that demographic diversity was likely to lead to positive outcomes when the organizational culture makes group membership salient and encourages people to categorize and identify to one another as having the organization's interest in common. More recently, many researchers have paid attention to fostering a diversity climate (Gonzalez, \& Denisi, 2009; McKay, Avery, \& Morris, 2008; McKay, Avery, Tonidandel, Morris, Hernandez, \& Hebl, 2007), while others have investigated the emergence of an inclusive climate (Mor Barak, Cherin, \& Berkman, 1998; Nishii, 2013; Shore, Cleveland $\&$ Sanchez, 2018). Both types of climates pursue the ideas that implementing an appropriate environmental context for diversity is a key factor to reach out to positive performance outcomes. Such climates create the right work environment capable of integrating employees' different viewpoints, insights, experiences, opinions, or identities, which in turn lead to reach positive outcomes in organizations.

In this study, we propose that the representation of diversity attributes (i.e., ethnicity, age, time worked, gender, disability, \& sexual orientation) among managers will influence the perception of a psychological diversity climate as well as inclusive climate in the organization. The more diverse the group is, the more likely managers will perceive their psychological climate as being diverse and inclusive.

Hypothesis 2a: Managers' diversity attributes predict a positive association with a psychological diversity climate. 
Hypothesis 2b: Managers' diversity attributes predict a positive association with a psychological inclusive climate and its three subdimensions (justice ${ }^{(b . a)}$, support ${ }^{(b . b)}$ and psychological safety ${ }^{(b . c)}$ ).

\section{Inclusive Leadership}

Inclusive leadership refers to leaders that are aware of, and understand diversity not only in terms of demographic characteristics but also in terms of perspectives, identities and approaches to work and encourage the true value of bringing together a variety of opinions and insights among different people (Hollander, 2009; Homan, Gundemir, Buengeler \& van Kleef, 2020). Research suggests that the perception of an inclusive leadership influences the creation of an inclusive climate (Shore, et al., 2011; Randel, Galvin, Shore, Ehrhart, Chung, Dean \& Kedharnath, 2018). In fact, without a strong commitment to diversity and inclusion coming from the top of the organization, the emergence of such climate among employees may never occur. An inclusive climate may only exist when employees perceive that the leadership enacts strategies that pursue the goal of successfully managing diversity and inclusion in the organization. We hypothesized as followed:

Hypothesis 3a: Managers' perception of an inclusive leadership in their organization predicts a positive association with a psychological diversity climate.

Hypothesis 3b: Managers' perception of an inclusive leadership in their organization predicts a positive association with a psychological inclusive climate and its three subdimensions (justice ${ }^{(b . a)}$, support ${ }^{(b . b)}$ and psychological safety ${ }^{(b . c)}$ ).

Comfort With Diversity and Openness to Diversity

Individuals vary on their level of openness to and comfort with diversity. These individual differences may be due to personality (i.e., especially the trait of openness to experience) and past experiences at interacting with diverse people. Those who shown interest in diversity are more likely to identify with diverse people, to feel psychologically closer to these people and learn more easily from their differences (Roberge, Petrov \& Huang, 2014). By being open to diversity, they may also feel more comfortable at interacting with people who are different from the self which overtime may make them more competent at managing diversity successfully and more likely to perceive their environment as being diverse and inclusive. We hypothesized as followed:

Hypothesis 4.1a: Managers' perception of their level of comfort with diversity predicts a positive association with a psychological diversity climate.

Hypothesis 4.1b: Managers' perception of their level of comfort with diversity predicts a positive association with a psychological inclusive climate and its three subdimensions (justice ${ }^{(b . a)}$, support ${ }^{(b . b)}$ and psychological safety ${ }^{(b . c)}$.

Hypothesis 4.2a: Managers' perception of their own openness to diversity predicts a positive association with a psychological diversity climate.

Hypothesis 4.2b: Managers' perception of their own openness to diversity predicts a positive association with a psychological inclusive climate and its three subdimensions (justice ${ }^{(b . a)}$, support ${ }^{(b . b)}$ and psychological safety ${ }^{(b . c)}$.

\section{Consequent Variables}

Regarding the consequent variables, this study focuses on examining whether both psychological climates predict, at the individual level, some attitudinal and behavioral outcomes. There are three attitudes that are examined: job satisfaction, job training satisfaction, and organizational commitment. As for the behavioral outcomes, the study examines voice behavior and prohibitive behavior. 


\section{Job Satisfaction and Job Training Satisfaction}

Job satisfaction is defined as the positive or negative attitude an employee has towards his or her job, including the surrounding work environment and co-worker (Ping Lima, Khun Loob \& Lee, 2017). In this study, we measure an overall perception of job satisfaction and propose that when employees perceive the psychological climate as being diverse and inclusive, which means that they feel fairly treated, supported and in a psychologically safe environment, they will be more satisfied with their job overall. Previous studies have largely disregarded the study of perceived positive diversity climate and job satisfaction and therefore as expressed by Madera, Dawson, and Guchait (2016) more research is needed in this area.

Job training satisfaction is defined as how people feel about aspects of the job training they received (Schmidt, 2007). Providing job training about diversity and inclusion to manager employees is considered enacting proactive and inclusive human resource practices that contribute to the emergence of an inclusive climate. Employees' satisfaction with the training received may be an important outcome variable to consider understanding the influence of providing such a training program on the diverse and inclusive climate. We propose that employees who perceive the psychological climates as being diverse and inclusive will be more satisfied with the training provided on the job.

Hypothesis 5.1a: A psychological diversity climate predicts a positive association with managers' job satisfaction.

Hypothesis 5.1b: A psychological inclusive climate and its 3 subdimensions (justice ${ }^{(b . a)}$, support ${ }^{(b . b)}$ and psychological safety $\left.{ }^{(b . c)}\right)$ predict managers' job satisfaction.

Hypothesis 5.2a: A psychological diversity climate predicts a positive association with managers' job training satisfaction.

Hypothesis 5.2b: A psychological inclusive climate and its three subdimensions (justice ${ }^{(b . a)}$, support ${ }^{(b . b)}$ and psychological safety ${ }^{(b . c)}$ ) predict a positive association with managers' job training satisfaction.

\section{Organizational Commitment}

Klein, Molly, and Brinsfield (2012) defined commitment as "a volitional psychological bond reflecting dedication to and responsibility for a particular target" (p. 137). In the case of our study, the target is the organization. We propose that employees will be more committed to their organization when they perceive being in a diversity climate and an inclusive climate that shows fairness, support and psychologically safety. When such work climates exist, employees will show a high level of commitment toward their organization. Indeed, fostering such diverse and inclusive climates met employees' expectations regarding how they want to be treated by their employer, leading them to reciprocate by showing a high level of organizational commitment (McKay, Avery, Liao, \& Morries, 2011).

Hypothesis 5.3a: A psychological diversity climate predicts a positive association with managers' organizational commitment.

Hypothesis 5.3b: A psychological inclusive climate and its three subdimensions (justice ${ }^{(b . a)}$, support ${ }^{(b . b)}$ and psychological safety ${ }^{(b . c)}$ ) predict a positive association with managers' organizational commitment.

\section{Voice Behavior}

Voice is defined as nonrequired behavior that emphasizes expression of constructive challenge with an intent to improve rather than merely criticize (LePine \& Van Dyne, 1998). An inclusive climate supports voice behavior in the organization by encouraging people to respectfully and openly express their disagreements, even when they are not part of the status quo. Such proactive behavior may be predicted by an inclusive climate, especially when the psychological safety climate is highly perceived among employees. 
Hypothesis 6.1a: A psychological diversity climate predicts a positive association with managers' voice behavior.

Hypothesis 6.1b: A psychological inclusive climate and its three subdimensions (justice ${ }^{(b . a)}$, support ${ }^{(b . b)}$ and psychological safety ${ }^{(b . c)}$ ) predict managers' voice behavior.

\section{Prohibitive Behavior}

Prohibitive behaviors, such as whistleblowing (Near \& Miceli, 1987; Miceli \& Near,1992), are critical and meant to stop some activity such as bullying or sexual harassment incidents in organizations. Under an inclusive climate, employees are more likely to speak up when facing difficult situations such as being either victim or witness of psychological or sexual harassment in organizations.

We proposed that when employees perceive the climate as being inclusive which means that they feel fairly treated, supported and psychological safe, the likelihood for them to display voice and prohibitive behaviors will increased.

Hypothesis 6.2a: A psychological diversity climate predicts a positive association with managers' prohibitive behavior.

Hypothesis 6.2b: A psychological inclusive climate and its three subdimensions (justice ${ }^{(b . a)}$, support ${ }^{(b . b)}$ and psychological safety ${ }^{(b . c)}$ ) predict managers' prohibitive behavior.

\section{METHOD}

\section{Sample}

An organizational field study was conducted after the delivery of a training program related to diversity, harassment, and inclusion. A survey was distributed to 38 managers, however, only 23 questionnaires were properly completed. Therefore, the sample is composed of 23 managers from an organization located in the Midwest of United States of America.

The organization who participated in this study was a distribution center. The sample was composed of 83 percent male managers and 17 percent female managers. In terms of their ethnicity, 22 percent were Asian; 30 percent were Latinos; 0 percent were American Indian; 17 percent African American; 26 percent were Caucasian; and the remainder, "other." As for the age, 30 percent were between 20 to 25 of age, 30 percent were between 26 to 30 of age, 4 percent were between 31 to 35 of age, 22 percent were between 36 to 40 of age, 14 percent were between 41 to 45,0 percent were older than 46 of age. No manager had a disability. As for their orientation sexual, 78 percent were heterosexual, 9 percent were homosexual, 13 percent were bisexual, and 0 percent were transgender. As for unit tenure, 22 percent had been working in their units for less than 1 year and the maximum work years is 4 years.

\section{Measures}

Following up on a diversity training program, the managers were invited to participate into this research project by completing a survey that measured the variables of interest. The studied mediator variables were measured by using 4 items that assessed the overall perception of a psychological diversity climate $(\alpha=.912)$ (McKay et al., 2008), and 19 items that assessed an overall perception of a psychological inclusive climate $(\alpha=.902)$, for which 6 items were used to assess justice $(\alpha=.739)$, (Mor Barak et al., 1998), 6 items to assess feeling of support $(\alpha=.869)$ (Eisenberger, et al., 2001), 7 items to assess psychological safety climate $(\alpha=.774)$ (Baer \& Frese,2003). The antecendent variables were measured by using 6 items that assessed diversity of attributes (ethinicty, age, time worked, gender, disability, and sexual orientation), 8 items that assessed inclusive leadership $(\alpha=.849)$ (Randel et al. 2018), 4 items that assesed perception of openess to diversity $(\alpha=.895)$, and 3 items that assessed personal comfort with diversity $(\alpha=.588)$ (Mor Barak et al., 1998). The consequence variables were measured by focusing on 3 attitudinal variables using, 4 items that assessed job satisfaction $(\alpha=.937)$ 
(Weiss et al., 1999), 11 items that assessed job training satisfaction $(\alpha=.909)$ (Schmidt (2004), and 4 items that assessed organizational commitment $(\alpha=.981)$ (Klein, Cooper, Molloy, \& Swanson, 2014). And, two behavioral variables were measured by using 6 items that assessed voice behavior $(\alpha=.893)$ (LePine \& Van Dyne, 1998), and 2 items that assessed prohibitive behavior $(\alpha=.310)$.

\section{Analyses}

A confirmatory factorial analysis was conducted to examine if the underlying psychological dimensions (justice, support, and psychological safety) could be considered all part of the psychological inclusive climate.

ANOVA analyses were conducted to determine whether the antecedent variables (diversity attributes, inclusive leadership, openness to and comfort with diversity) predict the emergence of a diversity climate and an inclusive climate. ANOVA analyses were also conducted to determine whether there were positive associations between the psychological climates and individual outcomes such as job satisfaction, job training satisfaction, organizational commitment voice behavior, and prohibitive behavior.

\section{RESULTS}

\section{Hypotheses Testing}

Table 1 presents the correlational relationships between psychological diversity climate, psychological inclusive climate and the antecedents and consequences at the individual level of analyses. We report the number of questions, the means, and the estimated standard deviations. The correlation matrix of the observable variables (or manifest variables) for inclusive climate was obtained and it was found that there are many correlations above 0.3, suggesting that clustering subgroups of variables is possible through factor analysis (Tabachnick \& Fidell 2001). The value for the Kaiser-Meyer-Olkin measure of sampling adequacy was 0.5 and Bartlett's test was significant. Principal components analysis was carried out and five factors emerged after varimax rotation. Table 2 shows that there is only one question for factor \#4 and one for factor \#5. Factor \#1, \#2, and \#3 account for the major variance, which is $62.45 \%$. Factor \#1 corresponds to 'justice dimension', accounting for $26.56 \%$ variance. Factor \#2 corresponds to 'support dimension', accounting for $22.58 \%$ variance. Factor \#3 corresponds to 'psychological safety dimension', accounting for $13.31 \%$ variance. Such results support hypothesis 1 stating that an inclusive psychological climate may be composed of three underlying psychological dimensions: justice, support, and psychological safety. 


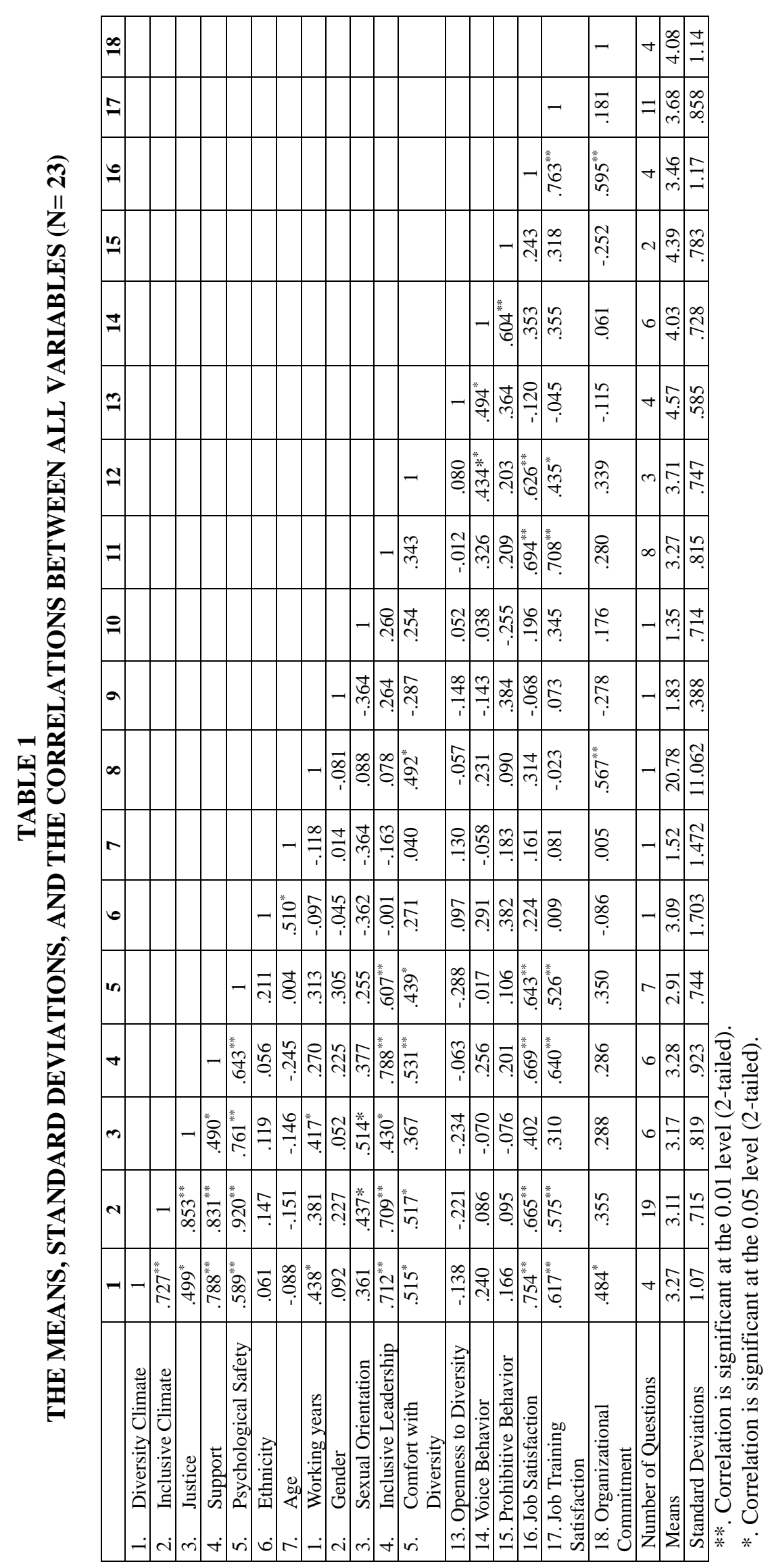

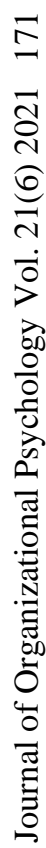


TABLE 2

TOTAL VARIANCE EXPLAINED

\begin{tabular}{|c|c|c|c|c|c|c|c|c|c|}
\hline \multirow[b]{2}{*}{$\begin{array}{c}\text { Questions } \\
\text { (Component) }\end{array}$} & \multicolumn{3}{|c|}{ Initial Eigenvalues } & \multicolumn{3}{|c|}{$\begin{array}{l}\text { Extraction Sums of Squared } \\
\text { Loadings }\end{array}$} & \multicolumn{3}{|c|}{$\begin{array}{c}\text { Rotation Sums of Squared } \\
\text { Loadings }\end{array}$} \\
\hline & Total & $\begin{array}{c}\% \text { of } \\
\text { Variance }\end{array}$ & $\begin{array}{c}\text { Cumulative } \\
\%\end{array}$ & Total & $\begin{array}{c}\% \text { of } \\
\text { Variance }\end{array}$ & $\underset{\%}{\text { Cumulative }}$ & Total & $\begin{array}{c}\% \text { of } \\
\text { Variance }\end{array}$ & $\begin{array}{c}\text { Cumulative } \\
\%\end{array}$ \\
\hline 1 & 7.909 & 41.627 & 41.627 & 7.909 & 41.627 & 41.627 & 5.046 & 26.560 & 26.560 \\
\hline 2 & 2.927 & 15.405 & 57.032 & 2.927 & 15.405 & 57.032 & 4.290 & 22.580 & 49.140 \\
\hline 3 & 1.824 & 9.601 & 66.633 & 1.824 & 9.601 & 66.633 & 2.528 & 13.308 & 62.448 \\
\hline 4 & 1.316 & 6.928 & 73.561 & 1.316 & 6.928 & 73.561 & 1.734 & 9.126 & 71.573 \\
\hline 5 & 1.063 & 5.595 & 79.157 & 1.063 & 5.595 & 79.157 & 1.441 & 7.583 & 79.157 \\
\hline 6 & .887 & 4.668 & 83.825 & & & & & & \\
\hline 7 & .637 & 3.354 & 87.179 & & & & & & \\
\hline 8 & .616 & 3.241 & 90.420 & & & & & & \\
\hline 9 & .472 & 2.486 & 92.906 & & & & & & \\
\hline 10 & .377 & 1.985 & 94.891 & & & & & & \\
\hline 11 & .268 & 1.409 & 96.300 & & & & & & \\
\hline 12 & .237 & 1.248 & 97.548 & & & & & & \\
\hline 13 & .151 & .794 & 98.342 & & & & & & \\
\hline 14 & .124 & .653 & 98.995 & & & & & & \\
\hline 15 & .089 & .468 & 99.463 & & & & & & \\
\hline 16 & .059 & .311 & 99.774 & & & & & & \\
\hline 17 & .027 & .141 & 99.915 & & & & & & \\
\hline 18 & .009 & .049 & 99.964 & & & & & & \\
\hline 19 & .007 & .036 & 100.000 & & & & & & \\
\hline
\end{tabular}


TABLE 3

CONFIRMATORY FACTOR ANALYSIS FACTOR LOADINGS:

ROTATED COMPONENT MATRIX

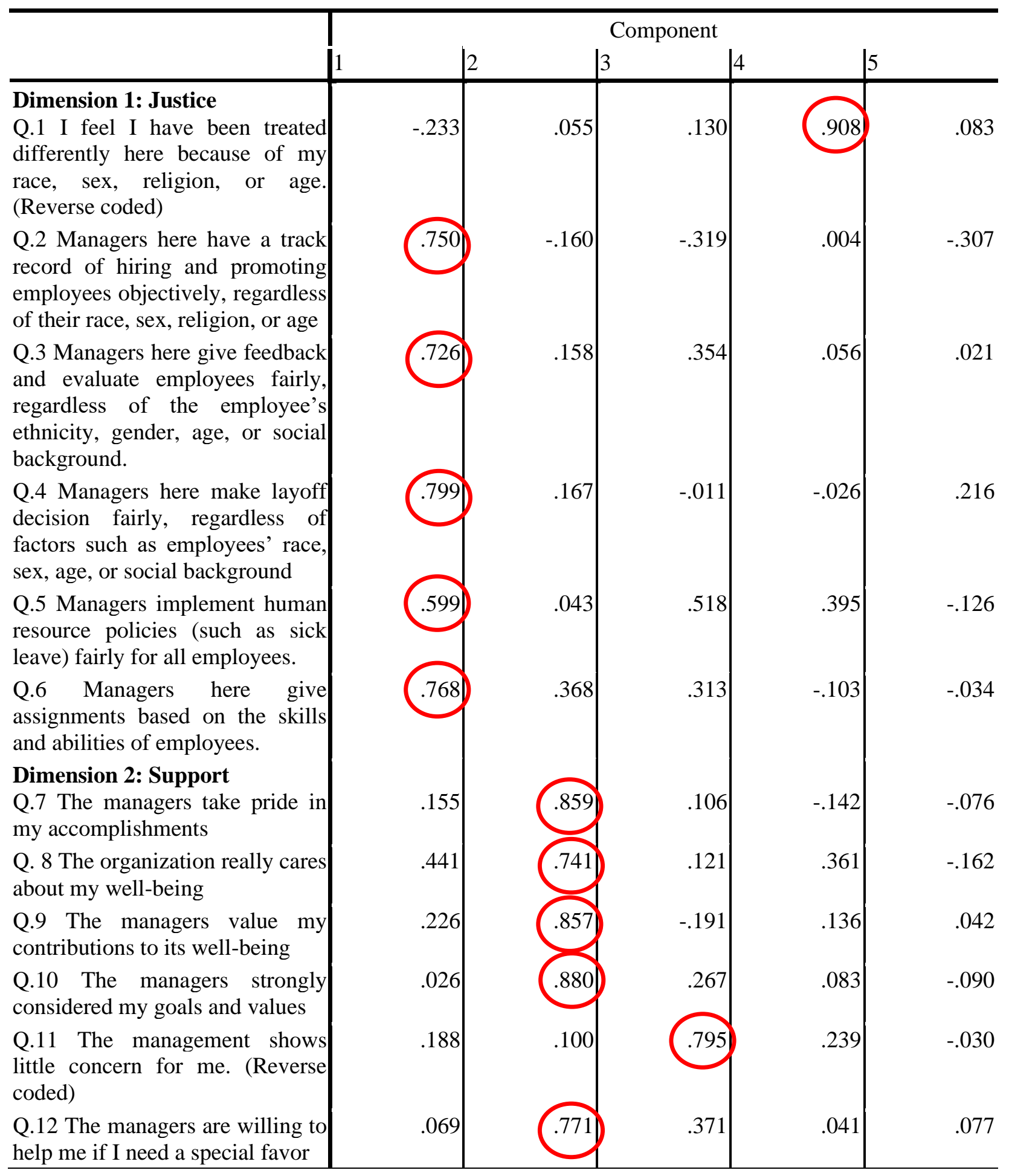




$\begin{aligned} & \text { Dimension 3: Psychological } \\ & \text { Safety } \\ & \text { Q.13 In our company some } \\ & \text { employees are rejected for being } \\ & \text { different. (Reverse coded) } \\ & \text { Q.14 When someone in our } \\ & \text { company makes a mistake, it is } \\ & \text { often held against them } \\ & \text { Q.15 No one in our company } \\ & \text { would deliberately act in a way } \\ & \text { that undermines others' efforts } \\ & \text { Q.16 It is difficult to ask others } \\ & \text { for help in our company? } \\ & \text { (Reverse coded) } \\ & \text { Q.17 In our company one is free } \\ & \text { to take risks } \\ & \text { Q.18 The people in our company } \\ & \text { value others' unique skills and } \\ & \text { talents } \\ & \text { Q.19 As an employee in our } \\ & \text { company, one is able to bring up } \\ & \text { problems and tough issues }\end{aligned}$

Extraction Method: Principal Component Analysis.

Rotation Method: Varimax with Kaiser Normalization.

Table 4 shows the antecedent variables that significantly predict a psychological diversity climate, which were time worked for the company $(F=5.283, \mathrm{p}<.05$, hypothesis 2 a was partially supported $)$, perception of an inclusive leadership $(F=21.607, \mathrm{p}<.01$, hypothesis $3 \mathrm{a}$. was supported $)$ as well as personal comfort with diversity $(F=7.561, \mathrm{p}<.05$, hypothesis $4.1 \mathrm{a}$ was supported $)$. Managers' perception of their openness to diversity was not significantly associated to a psychological diversity climate, which means that hypothesis $4.2 \mathrm{a}$ was refuted.

TABLE 4

RESULTS OF ANTECEDENT VARIABLES PREDICTING A PSYCHOLOGICAL DIVERSITY CLIMATE $^{(a)}$

\begin{tabular}{|c|c|c|c|c|c|}
\hline \multirow{2}{*}{$\begin{array}{l}\text { Antecedent Variables } \\
\text { Managers' diversity } \\
\text { attributes }\end{array}$} & $\begin{array}{l}\text { Sum of } \\
\text { Squares }\end{array}$ & $\overline{D f}$ & Mean Square & $F$ & Sig. \\
\hline & & & & & \\
\hline - Ethnicity & & & & & \\
\hline Regression & 3.161 & 4 & .790 & .644 & .638 \\
\hline Error & 22.078 & 18 & 1.227 & & \\
\hline Total & 25.239 & 22 & & & \\
\hline Regression & 2.322 & 4 & .583 & .458 & .765 \\
\hline Error & 22.907 & 18 & 1.273 & & \\
\hline $\begin{array}{r}\text { Total } \\
\text { - } \quad \text { Time worked }\end{array}$ & 25.239 & 22 & & & \\
\hline
\end{tabular}




\begin{tabular}{|c|c|c|c|c|c|}
\hline Regression & 5.073 & 1 & 5.073 & 5.283 & $.032 *$ \\
\hline Error & 20.166 & 21 & .960 & & \\
\hline _ Gender Total & 25.239 & 22 & & & \\
\hline Regression & .212 & 1 & .212 & .178 & .677 \\
\hline Error & 25.027 & 21 & 1.192 & & \\
\hline Total & 25.239 & 22 & & & \\
\hline $\begin{array}{ll}- & \text { Sexual } \\
& \text { orientation }\end{array}$ & & & & & \\
\hline Regression & 3.291 & 2 & 1.646 & 1.500 & .247 \\
\hline Error & 21.948 & 20 & 1.097 & & \\
\hline Total & 25.239 & 22 & & & \\
\hline Inclusive leadership & & & & & \\
\hline Regression & 12.799 & 1 & 12.799 & 21.607 & $.000 * *$ \\
\hline Error & 12.440 & 21 & .592 & & \\
\hline Total & 25.239 & 22 & & & \\
\hline $\begin{array}{l}\text { Personal comfort with } \\
\text { diversity }\end{array}$ & & & & & \\
\hline Regression & 6.681 & 1 & 6.681 & 7.561 & $.012 *$ \\
\hline Error & 18.558 & 21 & .884 & & \\
\hline Total & 25.239 & 22 & & & \\
\hline $\begin{array}{l}\text { Perception of own } \\
\text { openness to diversity }\end{array}$ & & & & & \\
\hline Regression & .483 & 1 & .483 & .410 & .529 \\
\hline Error & 24.756 & 21 & 1.179 & & \\
\hline Total & 25.239 & 22 & & & \\
\hline
\end{tabular}

Note. Two-tailed, $* \mathrm{p}<.05 ; * * \mathrm{p}<.01$.

Table 5 shows the antecedent variables that significantly predict a psychological inclusive climate which were time worked for the company $(\mathrm{F}=4.865, \mathrm{p}<.05$, hypothesis $2 \mathrm{~b}$ was partially supported), perception of inclusive leadership $(\mathrm{F}=21.251, \mathrm{p}<.01$, hypothesis $3 \mathrm{~b}$ was supported), as well as personal comfort with diversity $(\mathrm{F}=7.668, \mathrm{p}<.05$, hypothesis $4.1 \mathrm{~b}$ was supported). Managers' perception of their openness to diversity was not significantly associated to a psychological inclusive climate, which means that hypothesis $4.2 \mathrm{~b}$ was not supported.

Table 5 also shows the antecedent variables that significantly predicted perception of justice, which were diversity of sexual orientations $(\mathrm{F}=4.197, \mathrm{p}<.05$, hypothesis 2 (b.a) was partially supported), and perception of an inclusive leadership $(\mathrm{F}=4.756, \mathrm{p}<.05$, hypothesis 3 (b.a) was supported). The table shows the antecedent variables that significantly predicted perception of support which were perception of an inclusive leadership ( $\mathrm{F}=34.452, \mathrm{p}<.01$, hypothesis 3(b.b) was supported) and personal comfort with diversity $(\mathrm{F}=8.235, \mathrm{p}<.01$, hypothesis $4.1(\mathrm{~b} . \mathrm{b})$ was supported). None of the diversity attributes were predictive of support which means that hypothesis 2(b.b) was refuted. It also shows the antecedent variables that significantly predicted perception of psychological safety, which were perception of an inclusive leadership ( $\mathrm{F}=12.224, \mathrm{p}<.01$, hypothesis 3(b.c) was supported) and personal comfort with diversity $(\mathrm{F}=5.010, \mathrm{p}<.05$, hypothesis 4.1 (b.c) was supported). None of the diversity attributes were predictive of psychological safety which means that hypothesis 2(b.c) was refuted. 


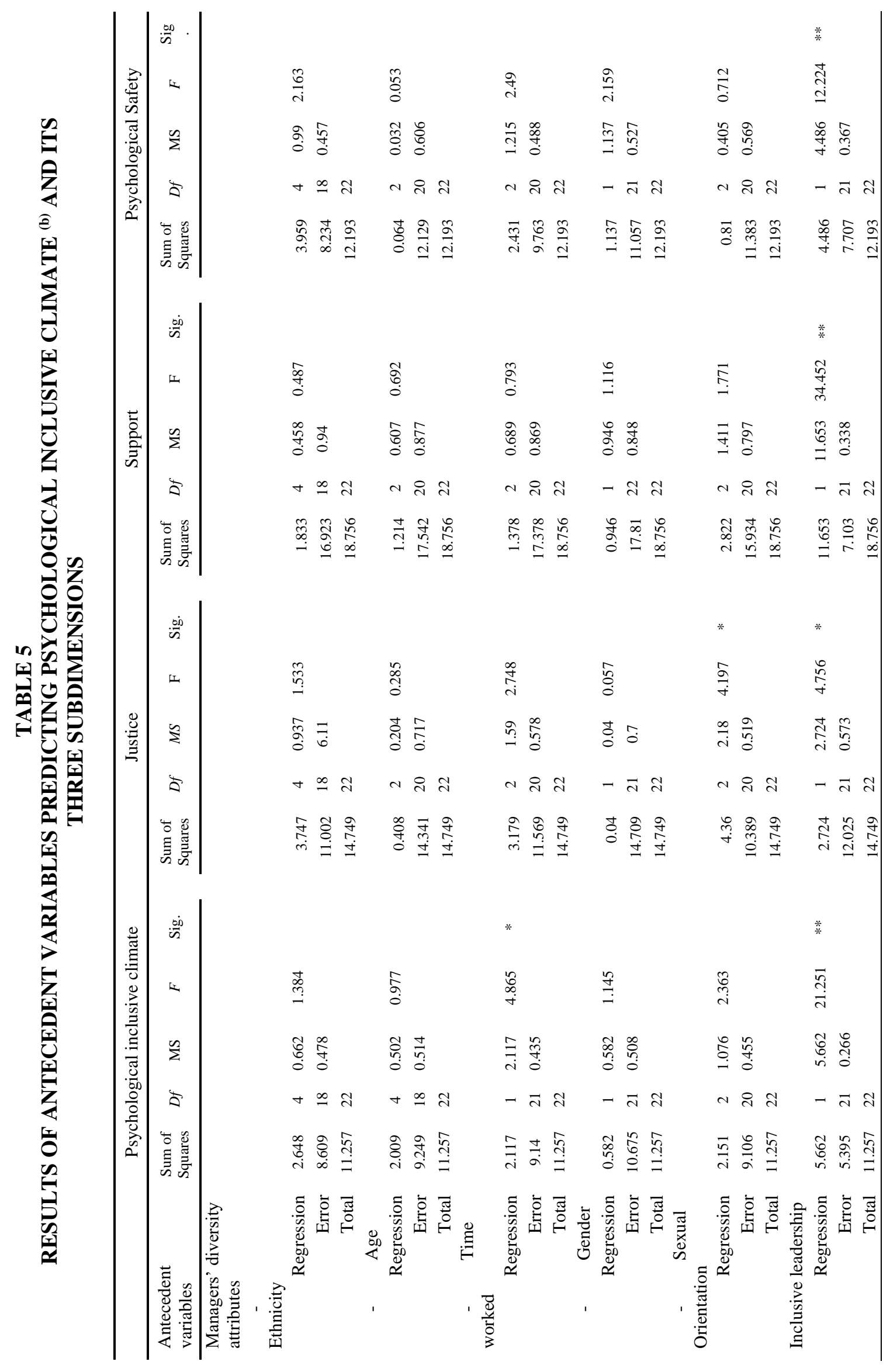

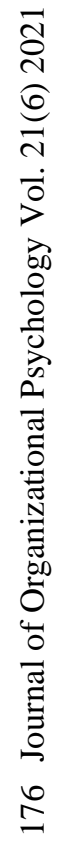




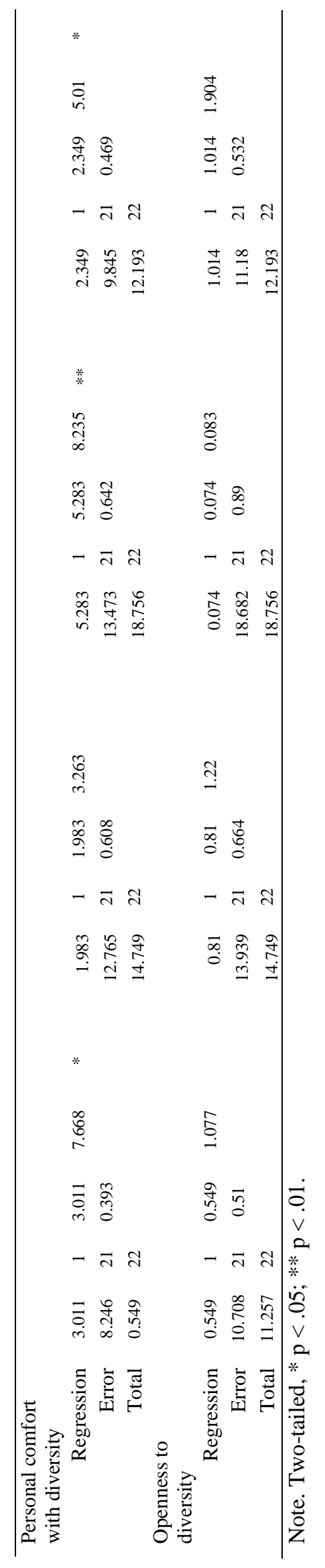


TABLE 6

RESULTS OF A PSYCHOLOGICAL DIVERSITY CLIMATE ${ }^{(a)}$ PREDICTING CONSEQUENCE VARIABLES

\begin{tabular}{|c|c|c|c|c|c|}
\hline Consequence variables & $\begin{array}{l}\text { Sum of } \\
\text { Squares }\end{array}$ & $D f$ & Mean square & $F$ & Sig. \\
\hline Job satisfaction & & & & & \\
\hline Regression & 17.095 & 1 & 17.095 & 27.644 & $000 * *$ \\
\hline Error & 12.986 & 21 & .618 & & \\
\hline Total & 30.082 & 22 & & & \\
\hline Job training satisfaction & & & & & \\
\hline Regression & 6.169 & 1 & 6.169 & 12.921 & $.002 * *$ \\
\hline Error & 10.027 & 21 & .477 & & \\
\hline Total & 16.196 & 22 & & & \\
\hline Org. commitment & & & & & \\
\hline Regression & 6.657 & 1 & 6.657 & 6.421 & $.019^{*}$ \\
\hline Error & 21.773 & 21 & 1.037 & & \\
\hline Total & 28.429 & 22 & & & \\
\hline Voice behavior & & & & & \\
\hline Regression & .669 & 1 & .669 & 1.281 & .271 \\
\hline Error & 10.978 & 21 & .523 & & \\
\hline Total & 11.647 & 22 & & & \\
\hline Prohibitive behavior & & & & & \\
\hline Regression & .370 & 1 & .370 & .592 & .450 \\
\hline Error & 13.109 & 21 & .624 & & \\
\hline Total & 13.478 & 22 & & & \\
\hline
\end{tabular}

Note. Two-tailed, $* \mathrm{p}<.05 ; * * \mathrm{p}<.01$. 


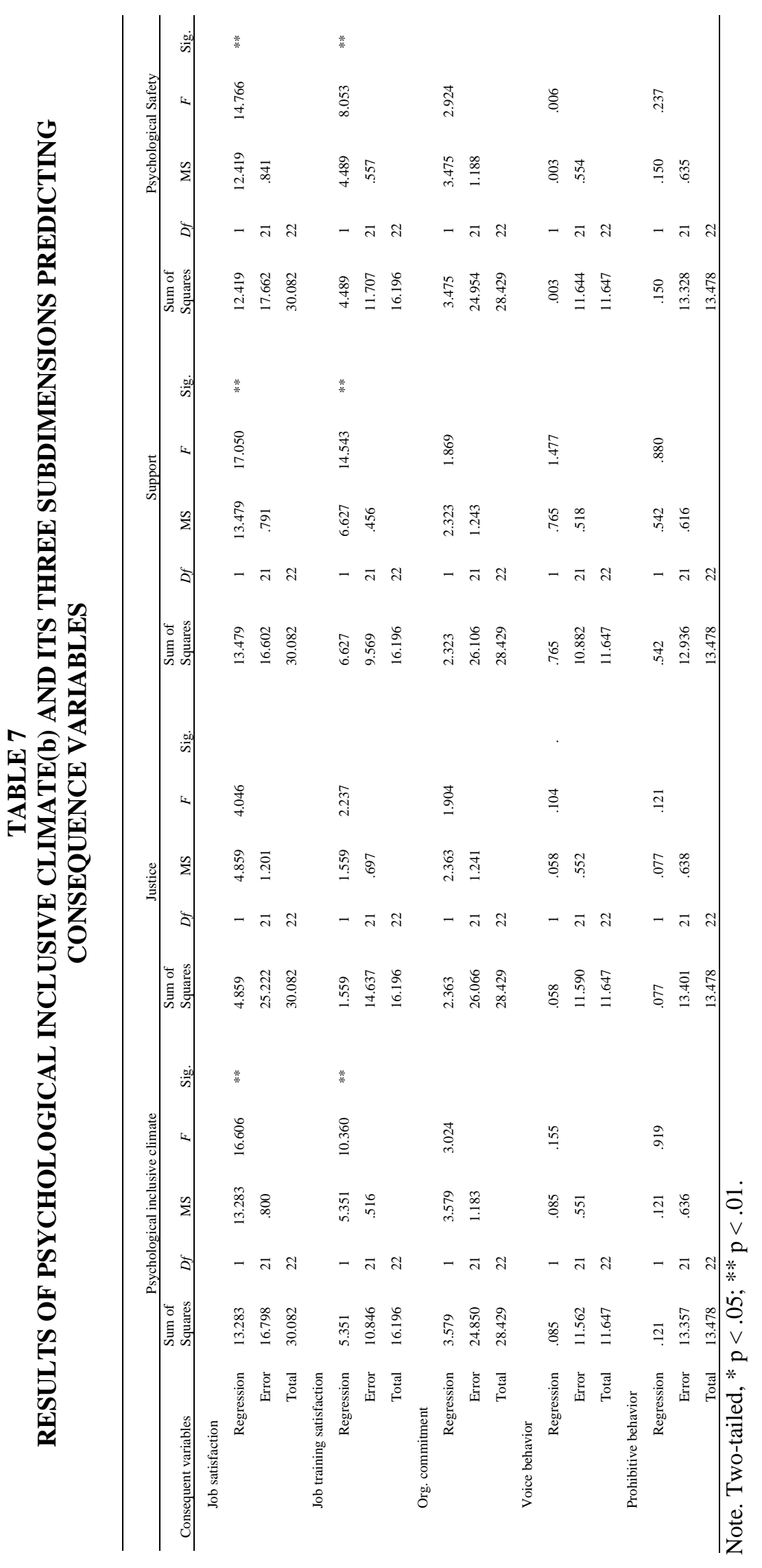


Table 6 shows that the relationships between a psychological diversity climate and the individual consequence variables were significant for job satisfaction $(F=27.644, \mathrm{p}<.01$, H5.1a was supported $)$, job training satisfaction $(F=12.921, \mathrm{p}<.01, \mathrm{H} 5.2 \mathrm{a}$ was supported $)$, and organizational commitment $(F=$ $6.421, \mathrm{p}<.05, \mathrm{H} 5.3 \mathrm{a}$ was supported). The relationships between psychological diversity climate with the voice behavior and prohibitive behavior were not significant, which means that hypotheses $6.1 \mathrm{a}$ and $6.2 \mathrm{a}$ were rejected.

Table 7 shows that the relationships between a psychological inclusive climate and the individual consequence variables were significant for job satisfaction $(F=16.606, \mathrm{p}<.01$, H5.1b was supported $)$, and job training satisfaction $(F=10.360, \mathrm{p}<.01, \mathrm{H} 5.2 \mathrm{~b}$ was supported). The relationship with organizational commitment was not significant which means that hypothesis $5.3 \mathrm{~b}$ was refused. The relationships between psychological inclusive climate with the voice behavior and prohibitive behavior were neither significant, which means that hypotheses $6.1 \mathrm{~b}$ and $6.2 \mathrm{~b}$ were refused.

While Table 8 shows that perception of justice did not predict any of the consequence variables, it shows that both perception of support and perception of psychological safety significantly predicted positive relationships with some attitudinal variables such as with job satisfaction $(F=17.050, \mathrm{p}<.01, \mathrm{H}$ 5.1(b.b) was supported, and $F=14.766, \mathrm{p}<.01, \mathrm{H}$ 5.1(b.c) was supported), and with job training satisfaction $(F=14.543, \mathrm{p}<.01, \mathrm{H} 5.2$ (b.b) was supported, and $F=8.053, \mathrm{p}<.01$, H 5.2(b.c) was supported). The relationships with organizational commitment was not significant, neither it was significant with the behavioral variables, which means that hypotheses 5.3 (b.b) and 5.3(b.c) and hypothesis 6.1(b.b), 6.1(b.c) and 6.2(b.b), 6.2(b.c) were refused.

\section{DISCUSSION}

The findings of this organizational field study first support the tri-dimensional conceptualization of an inclusive psychological climate. Perceptions of justice, support, and psychological safety are considered the latent constructs of such a climate. Then, the findings reveal that both psychological diversity climate and psychological inclusive climate are positively associated with the time worked for the organization. People who have worked longer time are more likely to perceive the work climates as being diverse and inclusive. Moreover, the result of this study suggests that managers who report perceiving the leadership as being inclusive are more likely to perceive the psychological climates as being both diverse and inclusive. Also, the findings reveal that managers who considered themselves comfortable with diversity are more likely to perceive the climate as being diverse and inclusive. Interestingly, the antecedents that significantly predicted perception of justice, dimension of an inclusive climate, were diversity of sexual orientations and inclusive leadership.

Perception of own openness to diversity might be a moderator instead of an antecedent variable. Those people who score higher on openness to diversity might be more likely to perceive the climate as being inclusive only when they perceive themselves as being comfortable with diversity. People who score low on openness to diversity might not perceive the climate as inclusive, even if they feel comfortable with diverse people. Openness is part of personality trait whereas being comfortable with diversity is a feeling. Both might interact with each other instead of being direct antecedent variables.

As for the consequences, both psychological climates, diverse and inclusive, were positively associated to job satisfaction and job training satisfaction. Only a psychological diversity climate was positively associated to organizational commitment. None of the hypotheses that were predicting positive relationships with voice behavior and prohibitive behavior were supported. Such findings show that the relationship between psychological climates and the consequences are significant for attitudinal variables, but not significant for behavioral variables, as it has often been found in the literature (Holmes et al., 2020)

\section{Limitations of the Study}

Our sample size is small, only 23 surveys were included into the analyses. Replicating this study by using a bigger sample size is recommended for future research to be able to generalize the results. The 
study conducted in this paper could somehow be considered as being a case study because of its limited numbers of participants. Moreover, because of its small sample size, the hypotheses that were not supported could have potentially become significant if the study would have had a bigger sample size. Therefore, it would be relevant to replicate this study with a bigger sample size and making sure that all participants complete the questionnaire adequately.

It would have been interesting to add a recent measure developed to assess inclusive climate, which focuses on the needs of belongingness and uniqueness (Chung, Ehrhart, Shore, Randel, Dean \& Kedharnath, 2020). Only measuring the three underlying psychological dimensions (justice, support \& psychological safety) could be seen as a weakness of our design.

Also, the relationships between the studied variables are assumed to be causal relationships. However, with the design of this field organizational study, we are limited to only examine correlational relationships between the variables. More research is needed to determine if the studied antecedent variables cause the creation of diversity and inclusive climates, and whether such climates have effects on outcome variables. With the design of this study, we can only reveal if there are associations between variables.

Another limitation to this study is that the effectiveness of the diversity training program, implemented prior to the data collection, was assessed only by the job training satisfaction variable. If data would have been collected before and after the diversity training program, we would have been able to measure the change caused by the diversity training program. Future studies could consider changing the design of this study to focus on how the diversity training program influences psychological climates.

\section{Theoretical Implications}

Both psychological climates, diverse and inclusive, were taken into consideration by this study. The proposed model and empirical study are a first attempt to study psychological diversity climate and psychological inclusive climate together. More studies should examine both concepts within the same study to determine the differences in between these psychological climates. Also, the model could be expanding by examining multi-level antecedents and consequences to the diversity and inclusive climates (Li, Perera, Kulik \& Metz, 2019). Further research could replicate and expand the proposed model by including multi-level variables and testing the model with a bigger sample size. More research is needed to perfect our understanding of the antecedents and consequences of a psychological diverse and inclusive work environment to assure that a diverse workforce becomes flourishing.

\section{Practical Applications}

The model can be used to identify strengths and weaknesses in terms of shaping managers' psychological diversity climate and psychological inclusive climate as well as predicting its individual consequences. It could be providing support to diagnose problems with the necessary climate for leveraging the advantages associated with a diverse workforce.

\section{CONCLUSION}

This paper sheds lights onto a theoretical model regarding the relationship between psychological climates (both diverse and inclusive), antecedents and individual level consequences. The tri-dimensional conceptualization of a psychological inclusive climate, that is, perceptions of justice, support and psychological safety was supported. Some antecedents such as time worked for the organization, the perception of inclusive leadership and personal comfort with diversity are significantly related to psychological climates. As to the consequences, it suggests that there are significant relationships between a psychological diversity climate and the three attitudinal variables - job satisfaction, job training satisfaction and organizational commitment. It also indicates that there are relationships between psychological inclusive climate and the two attitudinal variables, job satisfaction and job training satisfaction. The findings could be used to predict individual level consequences through managers' psychological work climates. 


\section{REFERENCES}

Baer, M., \& Frese, M. (2003). Innovation is not enough: Climates for initiative and psychological safety, process innovations, and firm performance. Journal of Organizational Behavior, 24, 45-68.

Batson, C.D. (1991). The altruism question: Toward a social-psychological answer. Hillsdale, NJ: Erlbaum.

Batson, C.D. (2010). Empathy-induced altruistic motivation. In M. Mikulincer \& P.R. Shaver (Eds.), Prosocial motives, emotions, and behavior: The better angles of our nature (pp. 15-53).

Washington, DC: American Psychological Association.

Batson, C.D., Polycarpou, M.P., Harmon-Jones, E., Imhoff, H.J., Mitchener, E.C., Bednar, L.L., . . . Highberger, L. (1997). Empathy and attitudes: Can feeling for a member of a stigmatized group improve feeling toward the group? Journal of Personality and Social Psychology, 7, 105-118.

Buttner, E.H., Lowe, K.B., \& Billings-Harris, L. (2010). Diversity climate impact on employee of color outcomes: Does justice matter? Career Development International, 15(3), 239-258.

Chatman, J., Polzer, J., Barsade, S., \& Neale, M. (1998). Being different yet feeling similar: The influence of demographic composition and organizational culture on work processes and outcomes. Administrative Science Quarterly, 43, 749-780.

Chrobot-Mason, D., \& Aramovich, N.P. (2013). The psychological benefits of creating and affirming climate for workplace diversity. Group \& Organization Management, 38(6), 659-689.

Chung, B.G., Ehrhart, K.H., Shore, L.M., Randel, A.E., Dean, M.A., \& Kedharnath, U. (2020). Work group inclusion: Test of a scale and model. Group \& Organization Management, 45(1), 75-102.

Cohen, S., \& Wills, T.A. (1985). Stress, social support, and the buffering hypothesis. Psychological Bulletin, 98, 310-357.

Colquitt, J.A., Conlon, D.E., Wesson, M.J., Porter, C.L.H., \& Ng, K.Y. (2001). Justice at the millennium: A meta-analytic review of 25 years of organizational justice research. Journal of Applied Psychology, 86(3), 425-445.

Doghan, M.A., Al Bhatti, M.A., \& Juhari, A.S. (2019). Do psychological diversity climate, HRM practices, and personality traits (Big Five) influence multicultural workforce job satisfaction and performance? Current Scenario, Literature Gap, and Future Research Directions. SAGE Open.

Dwertmann, D.J.G., Nishii, L.H., \& van Knippenberg, D. (2016). Disentangling the fairness \& discrimination and synergy perspectives on diversity climate: Moving the field forward. Journal of Management, 42, 1136-1168.

Edmondson, A. (1999). Psychological safety and learning behavior in work teams. Administrative Science Quarterly, 44, 350-383.

Eisenberger, R., Armeli, S., Rexwinkel, B., Lunch, P.D., \& Rhoades, L. (2001). Reciprocation of perceived organizational support. Journal of Applied Psychology, 86, 42-51.

Frazier, M.L., Fainshmidt, S., Kling, R.L., Pezeshkan, A., \& Vracheva, V. (2017). Psychological safety: A meta-analytic review and extension. Personnel Psychology, 70, 113-165.

Gonzalez, J.A., \& Denisi, A.S. (2009). Cross-level effects of demography and diversity climate on organizational attachment and firm effectiveness. Journal of Organizational Behavior, 30, 21-40.

Gower, A.L., Forster, M., Gloppen, K., Johnson, A.Z., Eisenberg, M.E., Connett, J.E., \& Borowsky, I.W. (2018). School practices to foster LGBT-supportive climate: Associations with adolescent bullying involvement. Prevention Science, 19, 813-821.

Haslam, S.A., O’Brien, A., Jetten, J., Vormedal, K., \& Penna, S. (2005). Taking the strain: Social identity, social support, and the experience of stress. British Journal of Social Psychology, 44, 355-370.

Herdman, A.O., \& McMillan-Capehart, A. (2010). Establishing a diversity program is not enough: Exploring the determinants of diversity climate. Journal of Business and Psychology, 25, 39-53.

Hicks-Clarke, D., \& Iles, P. (2000). Climate for diversity and its effects on career and organizational attitudes and perceptions. Personnel Review, 29, 324-345. 
Hollander, E.P. (2009). Inclusive leadership: The essential leader-follower relationship. New York, NY: Routledge.

Holmes, O., IV, Jiang, K., Avery, D.R., McKay, P., Oh, I., \& Tillman, C.J. (2020). A meta-analysis integrating 25 years of diversity climate research. Journal of Management. https://doi.org/10.1177/0149206320934547

Homan, A.C., Gundemir, S., Buengeler, C., \& van Kleef, G.A. (2020). Leading diversity: Toward a theory of functional leadership in diverse teams. Journal of Applied Psychology, 105(10), 11011128.

James, L.R., Choi, C.C., Ko, C.H.E., McNeil, P.K., Minton, M.K., Wright, M.A., \& Kim, K.I. (2008). Organizational and psychological climate: A review of theory and research. European Journal of Work and Organizational Psychology, 17(1).

Joshi, A., \& Roh, H. (2013). Understanding how context shapes team diversity outcomes. In Q.M. Roberson (Ed.), The Oxford handbook of diversity and work (pp. 209-219). New York, NY: Oxford University Press.

Kahn, W.A. (1990). Psychological conditions of personal engagement and disengagement at work. Academy of Management Journal, 33, 692-724.

Klein, H.J., Cooper, J.T., Molloy, J.C., \& Swanson, J. (2014). The assessment of commitment: Advantages of a unidimensional, target-free approach. Journal of Applied Psychology, 99, 222 238.

Klein, H.J., Molloy, J.C., \& Brinsfield, C.B. (2012). Reconceptualizing workplace commitment to redress a stretched construct: Revisiting assumptions and removing confounds. Academy of Management Review, 37, 130-151

Kochan, T., Bezrukova, K., Ely, R., Jackson, S., Joshi, A., Jehn, K., . . Thomas, D. (2003). The effects of diversity on business performance. Report of the diversity research network. Human Resource Management, 42, 3-21.

Leonardelli, G.J., Pickett, C., \& Brewer, M.B. (2010). Optimal distinctiveness theory: A framework for social identity, social cognition, and intergroup relations. Advances in Experimental Social Psychology, 43, 63-113.

LePine, J.A., \& Van Dyne, L. (1998). Predicting voice behavior in work groups. Journal of Applied Psychology, 83, 853-868.

Li, Y., Perera, S., Kulik, C., \& Metz, I. (2019). Inclusion climate: A multilevel investigation of its antecedents and consequences.

Luijters, K., Van der Zee, K., \& Otten, S. (2008). Cultural diversity in organizations: Enhancing identification by valuing differences. International Journal of Intercultural Relations, 32(2), 154 163.

Luthans, F., Norman, S.M., Avolio, B.J., \& Avey, J.B. (2008). The mediating role of psychological capital in the supportive organizational climate - employee performance relationship. Journal of Organizational Behavior, 29, 219-238.

Madera, J.M., Dawson, M., \& Guchait, P. (2016). Psychological diversity climate: Justice, racioethnic minority status and job satisfaction. International Journal of Contemporary Hospitality Management, 291, 2514-2532.

McKay, P.F., \& Avery, D.R. (2015). Diversity Climate in Organizations: Current Wisdom and Domains of Uncertainty. Research in Personnel and Human Resources Management, 33, 191-233. Emerald Group Publishing Limited, Bingley. https://doi.org/10.1108/s0742730120150000033008

McKay, P.F., Avery, D.R., \& Morris, M.A. (2008). Mean racial-ethnic differences in employee sales performance: The moderating role of diversity climate. Personnel Psychology, 61, 349-374.

McKay, P.F., Avery, D.R., Liao, H., \& Morries, M.A. (2011). Does diversity climate lead to customer satisfaction? It depends on the hospitality climate and business unit demography. Organization Science, 22, 788-803. 
McKay, P.F., Avery, D.R., Tonidandel, S., Morris, M.A., Hernandez, M., \& Hebl, M.R. (2007). Racial differences in employee retention: Are diversity climate perceptions the key? Personnel Psychology, 60, 35-62.

Miceli, M.E, \& Near, J.E (1992). Blowing the whistle: The organizational and legal implications for companies and employees. New York: Lexington Books.

Milton, L.P., \& Westphal, J.D. (2005). Identity confirmation networks and cooperation in groups. Academy of Management Journal, 48, 191-212.

Mor Barak, M.E., \& Cherin, D.A. (1998). A tool to expand organizational understanding of workforce diversity. Admin. Soc. Work, 22, 47-64.

Mor Barak, M.E., Cherin, D.A., \& Berkman, S. (1998). Organizational and personal dimension in diversity climate: Ethnic and gender differences in employee perceptions. Journal of Applied Behavioral Science, 34, 82-104.

Mor Barak, M.E., Lizano, E.L., Kim, A., Duan, L., Rhee, M., Hsiao, H., \& Brimhall, K. (2016). The promise of diversity Management for climate of inclusion: A State-of-the-Art review and metaAnalysis. Human Service Organizations: Management, Leadership \& Governance. DOI: 10.1080/23303131.2016.1138915

Near, J.P., \& Miceli, J.P. (1987). Whistle-blowers in organizations: Dissidents or reformers? In L.L. Cummings \& B.M. Staw (Eds.), Research in organizational behavior (Vol. 9, pp. 321-368). Greenwich, C'12.JAI Press.

Nishii, L.H. (2013). The benefits of climate for inclusion for gender-diverse groups. Academy of Management Journal, 56(6), 1754-1774.

Ping Lima, A.J., Khun Loob, J.T., \& Lee, P.H. (2017). The impact of leadership on turnover intention: The mediating role of organizational commitment and job satisfaction. Journal of Applied Structural Equation Modeling, 1, 27-42.

Randel, A.E., Galvin, B.M., Shore, L.M., Ehrhart, K.H., Chung, B.G., Dean, M.A., \& Kedharnath, U. (2018). Inclusive leadership: Realizing positive outcomes through belongingness and being valued for uniqueness. Human Resource Management Review, 28, 190-203.

Reimer, N.K., Schmid, K., Hewstone, M., \& Al Ramiah, A. (2020). Self-categorization and social identification: Making sense of us and them. In D. Chadee (Ed.), Theories in social psychology (2nd ed.). Wiley-Blackwell.

Rhoades, L., \& Eisenberger, R. (2002). Perceived organizational support: A review of the literature. Journal of Applied Psychology, 87, 698-714.

Roberge, M.É. (2013). A Multi-Level Conceptualization of Affective Empathy to Explain How Diversity Increases Group Performance. International Journal of Business and Management, 8(3), 122133.

Roberge, M.É., \& Van Dick, R. (2010). Recognizing the benefits of diversity: When and how does diversity increase group performance. Human Resource Management Review, 20, 295-308.

Roberge, M.É., Lewicki, R.J., Hietapelto, A. \& Abdyldaeva, A. (2011). From theory to practice: Recommending supportive diversity practices. Journal of Diversity Management, 6(2), 1-20.

Roberge, M.É., Petrov, E. \& Huang, W.R. (2014). Students' perceptions of their attitudes and behaviors toward different cultures/ethnicities before and after a diversity training program. Journal of Business Diversity, 14(1), 80-90.

Roberson, Q.M. (2019). Diversity in the workplace: A review, synthesis, and future research agenda. Annual Review of Industrial and Organizational Psychology and Organizational Behavior, 6, 6988.

Schmidt, S.W. (2004). The Relationship Between Satisfaction with On-The-Job Training and Overall Job Satisfaction. [Unpublished doctoral dissertation. University of Wisconsin, Milwaukee].

Schmidt, S.W. (2007) The relationship between satisfaction with workplace training and overall job satisfaction. Human Resource Development Quarterly, 18 (4), 481-498.

Seeman, T.E. (1996). Social ties and health: The benefits of social integration. Annuals of Epidemiology, $6,442-451$.

184 Journal of Organizational Psychology Vol. 21(6) 2021 
Shore, L.M., \& Shore, T.H. (1995). Perceived organizational support and organizational justice. In R. Cropanzano \& M. Kacmar (Eds.), Organizational politics, justice and support: Managing the social climate in the workplace (pp. 149-164). Westport, CT: Quorum Books.

Shore, L.M., Cleveland, J.N., \& Sanchez, D. (2018). Inclusive workplaces: A review and model. Human Resource Management Review, 28, 176-189.

Shore, L.M., Randel, A.E., Chung, B.G., Dean, M.A., Ehrhart, K.H., \& Singh, G. (2011). Inclusion and diversity in work groups: A review and model for future research. Journal of Management, 37, 1262-1289.

Stamper, C.L., \& Masterson, S.S. (2002). Insider or outsider? How employee perceptions of insider status affect their work behavior. Journal of Organizational Behavior, 23, 875-894.

Tabachnick, B., \& Fidell, L. (2001). Using multivariate statistics. Needham Heights: Allyn \& Bacon.

Tajfel, H. (1978). Social categorization, social identity, and social comparison. In H. Tajfel (Ed.), Differentiation between social groups (pp. 61-76). London: Academic Press.

Tasselli, S., Kilduff, M., \& Landis, B. (2018). Personality change: Implications for organizational behavior. Academy of Management Annals, 12, 467-493.

Turner, J.C., Hogg, M.A., Oakes, P.J., Reicher, S.D., \& Wetherell, M.S. (Eds.). (1987). Rediscovering the social group. Oxford: Blackwell.

Van der Vegt, G.S., \& Bunderson, J.S. (2005). Learning and performance in multidisciplinary teams: The importance of collective team identification. Academy of Management Journal, 48, 532-547.

Van Knippenberg, D., De Dreu, C.K.W., \& Homan, A.C. (2004). Work group diversity and group performance: An integrative model and research agenda. Journal of Applied Psychology, 89, 1008-1022.

Van Knippenberg, D., Nishii, L.H., \& Dwertmann, D.J.G. (2020). Synergy from diversity: Managing team diversity to enhance performance. Behavioral Science and Policy, 6(1), 75-92.

Weiss, H.M., Nicholas, J.P., \& Daus, C.S. (1999). An examination of the joint effects of affective experiences and job beliefs on job satisfaction and variations in affective experiences over time. Organizational Behavior and Human Decision Processes, 78, 1-24. 